\title{
Karakteristik Fisik Dan Kimia Nata De Milko Dari Susu Substandar Dengan Variasi Lama Inkubasi
}

\author{
R. A Tubagus ${ }^{1 \mathrm{a}}$, H. Chairunnissa ${ }^{1}$, R. L. Balia ${ }^{1}$ \\ ${ }^{I}$ Laboratorium Teknologi Pengolahan Produk Peternakan, Fakultas Peternakan, Univristas padjdjaran. \\ qemail: robi.tubagus@outlook.com
}

\begin{abstract}
Abstrak
Susu substandar didefinisikan sebagai susu segar yang tidak memenuhi persyaratan minimal yang ditetapkan oleh pemerintah dalam standar susu mutu segar sebagai susu segar. Namun demikian susu substandar tersebut masih mengandung karbon, nitrogen dan mineral sebagai sumber nutrisi bagi pertumbuhan Acetobacter xilinum dalam pembuatan Nata de Milko. Penelitian ini bertujuan untuk menentukan lama inkubasi yang optimum dan menghasilkan karakteristik fisik dan kimia Nata de Milko yang terbaik. Penelitian dilakukan menggunakan Rancangan Acak Lengkap (RAL) yang terdiri dari tiga perlakuan lama inkubasi pada pembuatan Nata de Milko yaitu 7 hari, 10 hari dan 13 hari yang masing-masing di ulangan enam kali. Hasil penelitian menunjukkan bahwa Nata de Milko dengan karakeristik fisik dan kimia terbaik diperoleh pada perlakuan lama inkubasi 13 hari, dengan nilai rendemen $43,65 \%$, ketebalan $1,74 \mathrm{~cm}$, tekstur $70,08 \mathrm{~mm} / \mathrm{g} / \mathrm{dt}$, kadar air $90,16 \%$, kadar abu $0,48 \%$, kadar lemak $0,32 \%$, kadar protein $0,61 \%$ dan karbohidrat $8,43 \%$.
\end{abstract}

Kata kunci: Susu substandar,karakteristik fisik, kimia, Nata de Milko, fermentasi.

\section{Physical And Chemical Characteristics Of Nata De Milko Made From Substandard Milk As Affecting By The Incubation Time}

\begin{abstract}
Substandard milk is defined as fresh milk that does not meet the minnimum requirements set by the government in this case BSN 2011 as fresh milk. in the other hand the substandard milk contains suitable source of carbon nitrogen and minerals for rapid growth of Acetobacter xylinum in processing of Nata de Milko. This study aims to determine the optimum incubation time in producing the best physical and chemical characteristics of Nata the Milko. A completely randomized design (CRD) was used in this study that consisted of 3 treaments incubation time of 7, 10 and 13 days, with six replations. The result concluded that the incubation time of 13 days prodused the best of nata the milko as the desired, with a yield value of $43.65 \%$, thickness $1,74 \mathrm{~cm}$, texture $70.08 \mathrm{~mm} / \mathrm{g} / \mathrm{dt}$, moisture $90.16 \%$, ash $0.48 \%, 0.32 \%$ fat, $0.61 \%$ protein and $8.43 \%$ carbohydrate contents.
\end{abstract}

Keywords: Substandard milk, characteristic physical, chemical, Nata de Milko, fermentation.

\section{Pendahuluan}

Susu merupakan salah satu hasil sekresi kelenjar ambing atau mamae dalam ternak. Susu ini diperoleh dari pemerahan ambing mamalia yang sehat dan mengandung lemak, protein, laktosa serta berbagai jenis garam dan vitamin, susu adalah cairan yang bergizi tinggi, baik untuk manusia maupun hewan muda dan cocok untuk media tumbuh mikroorganisme karena menyediakan berbagai nitrisi (Susilorini dan Sawitri, 2007). Susu murni atau susu segar merupakan hasil dari proses pemerahan dan belum mendapat perlakuan apapun kecuali pendinginan. Nilai gizinya yang tinggi menyebabkan susu menjadi media yang sangat cocok bagi mikroorganisme untuk pertumbuhan dan perkembangannya sehingga dalam waktu yang sangat singkat susu menjadi tidak layak dikonsumsi (Zakaria, et al., 2011).

Syarat mutu susu segar menurut SNI No 3141.1:2011 (BSN, 2011) antara lain berat jenis 1,0270, bahan kering tanpa lemak minimal $7,8 \%$, protein minimal 2,8\%, kadar lemak minimal 3\%, uji alkohol $70 \%$ negatif, $\mathrm{pH}$ 6,3-6,8 dan secara organoleptik tidak ada perubahan. Berdasarkan data yang diperoleh dari Badan Pusat Statistik (BPS, 2009-2016) 
produksi susu segar. Indonesia menghasilkan susu segar sebanyak 852.951 ton pada tahun 2016. Apabila dari susu segar tersebut 1\% saja yang tidak memenuhi persyaratan mutu tersebut maka dihasilkan sebanyak 8529 ton per tahun susu substandar.

Susu substandar didefinisikan sebagai susu murni yang tidak memenuhi persyaratan minimal yang ditetapkan oleh pemerintah dalam hal ini adalah BSN 2011 (Hartati, 1997), sebagai susu segar dan akan ditolak oleh perusahaan dan dikembalikan ke pihak penyetor. Setiap harinya, susu segar yang diterima di GKSI sekitar 45.000 liter dan susu segar yang ditolak sekitar 4.000 liter, sehingga banyak mengalami kerugian, karena kadangkadang dibuang begitu saja sehingga akan menimbulkan bau yang tidak dikehendaki dan dapat mencemari lingkungan. Untuk mengatasi masalah tersebut, susu substandar dapat digunakan sebagai bahan baku dalam pembuatan Nata dan masih mengandung karbon, nitrogen dan mineral sebagai sumber nutrisi untuk pertumbuhan bakteri Acetobacter xylinum.

Nata adalah lapisan polisakarida ekstraseluler (selulosa) yang dibentuk oleh kumpulan sel bakteri pembentuk kapsul. Lapisan ini mempunyai tekstur kenyal, putih, menyerupai gel dan terapung pada bagian permukaan cairan (Hardi dan Abdullah 2013). Umumnya pembuatan Nata menggunakan sumber bahan utama berupa air kelapa yang disebut Nata de Coco. Pembuatan Nata diikuti dengan penambahan bahan penunjang antara lain nitogen (urea food grade) disamping perkayaan media dan karbohidrat (gula sukrosa) yang ditambahkan sebagai sumber karbon dalam aktivitas fermentasi, untuk menghasilkan komponen polisakarida atau lapisan Nata (Nugroho dan Pradipta. 2015). Beberapa Nata yang telah dikembangkan di Indonesia antara lain: Nata de Cacao, Nata de Soya, Nata de Banana, Nata de Aren, Nata de Pina dan Nata de Milko. Berbagai macam nama Nata disesuaikan dengan bahan baku utama yang digunakan sebagai media pembuatan Nata. Contoh Nata de Milko, berarti bahan baku utamanya dari susu.

Penggunaan susu substandar dengan kriteria $\mathrm{pH}$ 6,2 merupakan media yang baik untuk pertumbuhan bakteri dalam membentuk Nata. Beberapa keunggulan susu substandar sebagai bahan baku pembuatan Nata adalah memiliki nutrien yang dibutuhkan bakteri
Acetobacter xylinum, seperti terdapat unsur $\mathrm{N}$ (nitrogen) dan mineral yang nantinya digunakan untuk pertumbuhan Acetobacter xylinum dan sebagai alternatif penggunaan sumber nitrogen dari bahan kimia. Kandungan protein pada susu substandar yang kompleks harus dihidrolisis terlebih dahulu membentuk asam amino dan peptida-peptida sederhana dengan kombinasi Bakteri Asam Laktat (BAL) yaitu Streptococcus thermophilus dan Lactobacillus bulgaricus 1:1 dalam fermentasi laktat (Shihata dan Shah, 2000) dan dipanen pada saat $\mathrm{pH}$ mencapai 4,$5 ; \mathrm{pH}$ tersebut merupakan $\mathrm{pH}$ optimum untuk pertumbuhan bakteri Acetobacter xylinum sehingga tidak perlu penambahan asam asetat untuk menurun $\mathrm{pH}$, karena sudah tergantikan oleh asam laktat.

Hal lain yang menunjang pertumbuhan bakteri Nata adalah suhu kirasan $28^{\circ} \mathrm{C}$ (Khairul, et al.,2015), pH berkirasar antara 4.0-5.0 Keshk et al. 2006) dan dibutuhkan ketersediaan gula sederhana (glukosa, fruktosa dan sukrosa) dan tersedianya unsur nitrogen (N) yang berpengaruh terhadap karakteristik Nata yang dihasilkan dan Pembentukan Nata dapat dipengaruhi oleh lama fermentasi, dimana lama fermentasi yang optimum akan menghasilkan kualitas Nata terbaik, pada percobaan pembuatan Nata de Cassava lama fermentasi hari ke 13 memberikan hasil yang optimum dengan ketebalan tertinggi yaitu sebesar 1,37 cm, rendemen 59,09\%. Pada penelitian ini Salah satu faktor yang dapat mempengaruhi karakteristik Nata adalah lama fermentasi.

\section{Materi dan Metode}

Penelitian ini dilaksanakan melalui beberapa tahapan, yaitu 1) Analisis bahan baku susu substandar, 2) Proses pengasaman (fermentasi laktat) susu substandar dengan bakteri asam laktat, 3) Analisis $\mathrm{C} / \mathrm{N}$ ratio pada bakal Nata de Milko, dan 4) Dilanjutkan dengan proses pembuatan Nata.

\section{Fermentasi Bakteri Asam Laktat (Modifikasi Roostita L, et al., 2011)}

Proses pengasaman (fermentasi laktat) meliputi : Penyaringan susu substandar, kemudian penambahan susu skim bubuk 5\% $(\mathrm{b} / \mathrm{v}) \quad$ seiring pemanasan, selanjutnya dinginkan hingga suhu turun menjadi $42^{\circ} \mathrm{C} \pm 2^{\circ} \mathrm{C}$, lalu inokulasi sebanyak $5 \%(\mathrm{v} / \mathrm{v})$ bulk culture $S$. thermophilus dan L. bulgaricus 
1:1 dan inkubasi selama 4 jam sampai dicapai $\mathrm{pH} 4,5$.

\section{Proses Pembuatan Nata de Milko (Modifikasi Alwani dan Kristiono, 2013)}

Setelah proses pengasaman media dilanjutkan dengan penambahan gula (sukrosa) $15 \%(\mathrm{~b} / \mathrm{v})$, lalu dilakukan pemanasan selama 15 menit pada suhu $85^{\circ} \mathrm{C} \pm 2^{\circ} \mathrm{C}$, selanjutnya dinginkan sampai suhu $28^{\circ} \mathrm{C} \pm 2^{\circ} \mathrm{C}$ dan tambahkan starter Acetobacter xylinum 15\% (v/v) masukan kedalam jar kaca sebanyak $150 \mathrm{ml}$ pada masing-masing perlakuan lalu ditutup bagian atas dengan kertas koran bekas dan ikat dengan karet, lalu inkubasi berdasarkan perlakuan 7 hari, 10 hari dan 13 hari, pada suhu $28^{\circ} \mathrm{C} \pm 2^{\circ} \mathrm{C}$. Masing-masing perlakuan melewati proses pencucian, pelepasan kulit ari Nata dan pemanasan (tanpa pemberian konsentasi gula).

\section{Rancangan Percobaan}

Penelitian dilakukan dalam 2 tahap: Tahap ke-1 analisis bahan baku susu subsstandar dan dilakukan analisis secara deskriptif. dalam analisis susu substandar dan analisis $\mathrm{C} / \mathrm{N}$ ratio sebagai bahan baku bakal Nata de Milko. Selanjutnya tahap ke-2 dilakukan secara eksperimental menggunakan Rancangan Acak Lengkap (RAL) yang terdiri dari tiga perlakuan lama inkubasi pada pembuatan Nata de Milko yaitu 7 hari, 10 hari dan 13 hari yang masing-masing di ulangan enam kali dengan enam kali pengulangan dan dilanjutkan dengan menggunakan uji Tukey taraf $0,05 \%$. Perhitungan mengunakan software Statistical Analysis System (SAS) Version 9.00.

\section{Peubah Penelitian Nata de Milko}

Analisis Bakal Nata de Milko (Deskriptif)

Peubah yang diamati meliputi : 1)

Analisis Susu menggunakan Lactoscan MCC50, 2) Kadar protein Metode Kjeldahl (AOAC, 1990), 3) Kadar gula total Metode Luff Schoorl (AOAC, 1995) dan 4)Analisis $\mathrm{C} / \mathrm{N}$ ratio (Junaidi, 2010).

\section{Berdasarkan Lama Fermentasi (Eksperimental)}

Peubah yang diamati meliputi : 1) Sifat fisik Nata de Milko dari susu substandar : (ketebalan (AOAC, 2007), tekstur (Dwi, A., et al. 2015) dan rendemen (AOAC, 2007)). 2) Sifat kimia Nata de Milko dari susu substandar: (kadar air (AOAC, 1990), kadar abu (AOAC, 1990), kadar lemak (AOAC, 1990), kadar protein metode Kjeldahl (AOAC, 1990) dan kadar karbohidrat (by difference) Winarno (1997).

\section{Hasil dan Pembahasan \\ Analisis Bakal Nata de Milko (Deskriptif)}

Tabel 1 menunjukkan bahwa terjadi penurunan mutu susu sapi segar yang diterapkan Badan Standardisasi Nasional (BSN, 2011) antara lain, bahan kering tanpa lemak minimal $7,8 \%$, protein minimal $2,8 \%$, dan $\mathrm{pH}$ 6,3-6,8. Hal ini dimungkinkan selama penyimpanan terjadi kontaminasi dan pemberian ransum yang tidak baik sehingga terjadi penurunan komponen kimia pada susu sapi segar, bakteri yang mengontaminasi susu dibagi menjadi dua yaitu bakteri patogen dan pembusuk. Bakteri patogen meliputi Staphylococcus aureus, Escherichia coli, dan Salmonella $s p$, sedangkan untuk bakteri pembusuk antara lain adalah Micrococcus $s p$, Pseudomonas sp, dan Bacillus sp (Suwito, 2010).

Menurut penelitian Mc Donald., et al. (2002). Peningkatan kadar protein pada susu tergantung pada asupan protein dalam pakan ternak yang membentuk asam amino dan diserap tubuh melalui darah. Nilai protein susu dipengaruhi oleh pemberian konsentrat. Semakin tinggi pemberian konsentrat maka semakin tinggi kadar protein susu (Sukarni, 2006), dan lemak susu tergantung dari kandungan serat kasar dalam pakan (Sudono., et al. 2003). Hal ini didukung oleh Siregar (2001).

Tabel 1. Komposisi Kimia Susu Substandar dengan Menggunakan Lactoscan

\begin{tabular}{lc}
\hline \multicolumn{1}{c}{ Komponen } & Kadar \\
\hline Lemak & $3,43 \%$ \\
Bahan kering tanpa lemak & $4,64 \%$ \\
Protein & $2,76 \%$ \\
Laktosa & $2,43 \%$ \\
pH & 6,2 \\
\hline
\end{tabular}


Tabel 2. Karakterisrik Kimia Bahan Baku Bakal Nata de Milko

\begin{tabular}{ccccc}
\hline $\mathbf{p H}$ & Total karbohidrat \% & Total nitrogen \% & Total protein \% & C/N ratio \% \\
\hline $4,52 \pm 0,02$ & $8,28 \pm 0,12$ & $0,20 \pm 0,01$ & $1,17 \pm 0,04$ & $42,15 \pm 1,87$ \\
\hline
\end{tabular}

Jenis pakan yang diberikan akan mempengaruhi produksi, kualitas susu dan kesehatan sapi perah. Susu sapi segar tidak memenuhi persyaratan minimal yang ditetapkan oleh pemerintah dalam hal ini adalah BSN 2011 disebut sebagai susu substandar (Hartati, 1997).

Tabel 2 menunjukkan setelah mengalami pengasaman (fermentasi laktat) terjadi penurunan $\mathrm{pH}$ dan protein hal ini disebabkan karena aktivitas Bakteri Asam Laktat (BAL). Menurut Hartati et al (2017) pada saat proses fermentasi berlangsung, bakteri starter akan merombak laktosa dalam bahan baku susu menjadi glukosa dan galaktosa oleh enzim laktase, dan kemudian membentuk asam laktat. Hal ini menyebabkan $\mathrm{pH}$ susu akan turun dan mengubah rasa susu menjadi asam yang khas. Bakteri starter dapat menghasilkan enzim protease, yang pada gilirannya menyebabkan protein menjadi terhidrolisis menjadi komponen protein yang paling sederhana yaitu peptidapeptida dan asam amino yang merupakan protein terlarut yang pada gilirannya merupakan sebagai sumber nitrogen pada pembuatan Nata.

\section{Karakteristik Nata De Milko Rendemen}

Tabel 3. Menunjukkan bahwa semakin lama inkubasi, rendemen Nata de Milko yang dihasilkan nyata meningkat. Hal ini dipengaruhi oleh adanya aktivitas bakteri Acetobacter xylinum yang menghasilkan enzim ekstraseluler (gluko polimerase) sebagai penyusun (mempolimerisasi) zat gula (glukosa) menjadi ribuan rantai (homopolimer) serat atau selulosa. Peningkatan jasad renik yang tumbuh dalam media akan menghasilkan jutaan lembar benang-benang selulosa yang terlihat padat berwarna putih sampai transparan yang disebut Nata dan termasuk hasil metabolit sekunder (Nainggolan, 2009).

Hasil penelitian ini sesuai dengan yang dilaporkan oleh Indah dan Siti (2013) bahwa meningkatnya lama fermentasi sampai hari ke13 akan menghasilkan rendemen yang lebih tinggi $(59,09 \%)$ pada pembuatan Nata de Cassava. Rendemen Nata de Milko tertinggi adalah $43,65 \%$ pada lama inkubasi hari ke-13 dibandingkan dengan lama inkubasi hari ke-10 $(33,67 \%)$ dan lama inkubasi hari ke-7 (19,59 $\%)$

\section{Ketebalan}

Tabel 3. Menunjukkan bahwa semakin lama inkubasi, ketebalan Nata de Milko yang dihasilkan nyata meningkat. Hal ini dipengaruhi oleh lama fermentasi dapat menyebabkan selulosa hasil sekresi Acetobacter xylinum akan berikatan kuat satu dengan yang lainnya membentuk lapisanlapisan yang terus menebal, hal ini menggambarkan bahwa lama fermentasi mempengaruhi aktivitas bakteri Accetobacter xylinum dalam menghasilkan Nata (Jannur., et al. 2015)

Hasil penelitian Awang (1991) lama fermentasi pada umumnya 2-4 minggu berpengaruh terhadap pembentukan selulosa Nata yang dicerminkan dengan ketebalan produk. Penggunaan lama fermentasi yang kurang tepat akan menyebabkan produk yang dihasilkan tidak optimal dalam menghasilkan selulosa. Hasil penelitian ini didukung oleh penelitian (Indah dan Siti, 2013) Bahwa pada produk Nata de Cassava terbaik dihasilkan pada lama fermentasi hari ke-13 dengan ketebalan tertinggi yaitu sebesar $1,37 \mathrm{~cm}$. Ketebalan Nata de Milko tertinggi adalah 1,74 $\mathrm{cm}$ pada lama inkubasi hari ke-13 dibandingkan dengan lama inkubasi hari ke-10 $(1,23 \mathrm{~cm})$ dan lama inkubasi hari ke-7 $(06,62$ $\mathrm{cm})$.

\section{Tekstur}

Tabel 3. Menunjukkan bahwa semakin lama inkubasi, tekstur Nata de Milko yang dihasilkan nyata menurun. Hal ini disebabkan semakin lama waktu inkubasi maka selulosa Nata dihasilkan semakin tinggi, sehingga tekstur Nata menjadi keras. Tekstur Nata dipengaruhi oleh komponen serat yang terdapat dalam Nata. Tekstur terbentuk karena ikatan $\mathrm{N}$ dengan prekusor polisakarida yang ada (Fifendy et al., 2011). Nata yang mempunyai kadar serat yang tinggi dan susunan serat yang rapat akan menghasilkan Nata yang kenyal. Nata tersusun oleh jaringan mikrofibril atau pelikel yang merupakan tipe 
selulosa yang mempunyai struktur kimia seperti selulosa yang dibentuk oleh tumbuhan tingkat tinggi (Iguchi et al., 2000).

Hasil penelitian ini didukung oleh Khothibul., et al. (2011). Bahwa semakin lama waktu inkubasi maka akan menghasilkan selulosa yang semakin banyak dan tekstur Nata yang kenyal, karena masih tersedianya nutrisi yang cukup sehingga bakteri secara terus menerus melakukan metabolisme dan reproduksi yang cukup tinggi. Monomermonomer selulosa hasil sekresi Acetobacter xylinum terus berikatan satu dengan yang lainnya membentuk lapisan-lapisan yang terusmenerus menebal seiring dengan berlangsungnya metabolisme Acetobacter xylinum. Tekstur Nata de Milko tertinggi adalah $88,38 \mathrm{~mm} / \mathrm{g} / \mathrm{dt}$ pada lama inkubasi hari ke-7 dibandingkan dengan lama inkubasi hari ke-10 $(81,52 \mathrm{~mm} / \mathrm{g} / \mathrm{dt})$ dan lama inkubasi hari ke-13 $(70,08 \mathrm{~mm} / \mathrm{g} / \mathrm{dt})$.

pH

Tabel 4. Menunjukkan bahwa semakin lama inkubasi, pH pada media Nata de Milko yang dihasilkan nyata menurun. Hal ini dipengaruhi oleh aktivitas bakteri Acetobacter xylinum selain menghasilkan Nata dapat menkonversi glukosa menjadi asam glukonat melalui jalur fosfat pentosa oleh bakteri asam asetat, sebagian besar fruktosa diubah menjadi asam asam organik (Marwati., et al. 2013).

Berdasarkan nilai rata-rata antar pelakuan terjadi penurunan $\mathrm{pH}$ yang dipengaruhi oleh lama inkubasi, pada hari 0 $\mathrm{pH}$ awal semua perlakuan 4,5 dimana semakin lama inkubasi asam-asam organik terbentuk akan semakin banyak dan membuat $\mathrm{pH}$ menurun. Hasil penelitian ini didukung oleh Naidu (2000), bahwa asam asetat yang terlarut akan terdisosiasi untuk melepaskan protonproton bebas yang menyebabkan penurunan $\mathrm{pH}$ medium, dengan menurunnya $\mathrm{pH}$ maka total asam akan meningkat. Sehingga lama fermentasi berpengaruh pada peningkatan total asam. Semakin lama inkubasi Nata de Milko maka total asamnya akan meningkat, $\mathrm{pH}$ Nata de Milko tertinggi adalah 4,21 pada lama inkubasi hari ke-7 dibandingkan dengan lama inkubasi hari ke-10 $(4,16)$ dan lama inkubasi hari ke-13 $(4,11)$.

Tabel 3. Karakteristik Fisik Nata de Milko

\begin{tabular}{lccc}
\hline \multirow{2}{*}{ Peubah } & \multicolumn{3}{c}{ Perlakuan } \\
\cline { 2 - 4 } & $\mathbf{7}$ hari & $\mathbf{1 0}$ hari & $\mathbf{1 3 ~ h a r i}$ \\
\hline Rendemen \%(b/v) & $19,59^{\mathrm{c}}$ & $33,67^{\mathrm{b}}$ & $43,65^{\mathrm{a}}$ \\
Ketebalan (cm) & $06,62^{\mathrm{c}}$ & $1,23^{\mathrm{b}}$ & $1,74^{\mathrm{a}}$ \\
Tekstur (mm/g/dt) & $88,38^{\mathrm{a}}$ & $81,52^{\mathrm{b}}$ & $70,08^{\mathrm{c}}$ \\
\hline
\end{tabular}

Keterangan: Huruf yang berbeda ke arah horizontal pada kolom yang sama menunjukkan berbeda nyata

Tabel 4. Karakteristik Kimia Nata de Milko

\begin{tabular}{lccc}
\hline \multirow{2}{*}{\multicolumn{1}{c}{ Peubah }} & \multicolumn{3}{c}{ Perlakuan } \\
\cline { 2 - 4 } & 7 hari & 10 hari & 13 hari \\
\hline pH Akhir & $4,21^{\mathrm{a}}$ & $4,16^{\mathrm{b}}$ & $4,11^{\mathrm{c}}$ \\
Kadar Air (\%) & $94,36^{\mathrm{a}}$ & $91,40^{\mathrm{b}}$ & $90,16^{\mathrm{c}}$ \\
Kadar Abu (\%) & $0,27^{\mathrm{c}}$ & $0,36^{\mathrm{b}}$ & $0,48^{\mathrm{a}}$ \\
Kadar Lemak (\%) & $0,14^{\mathrm{c}}$ & $0,24^{\mathrm{b}}$ & $0,32^{\mathrm{a}}$ \\
Kadar Protein (\%) & $0,34^{\mathrm{c}}$ & $0,47^{\mathrm{b}}$ & $0,61^{\mathrm{a}}$ \\
Kadar Karbohidrat (\%) & $4,89^{\mathrm{c}}$ & $7,54^{\mathrm{b}}$ & $8,43^{\mathrm{a}}$ \\
\hline
\end{tabular}

Keterangan: Huruf yang berbeda ke arah horizontal pada kolom yang sama menunjukkan berbeda nyata 


\section{Kadar air}

Tabel 4. Menunjukkan bahwa semakin lama inkubasi, kadar air Nata de Milko yang dihasilkan nyata menurun. Hal ini dipengaruhi oleh banyak tidaknya kandungan serat yang dihasilkan Acetobacter xylinum selama fermentasi berlangsung, semakin lama fermentasi maka menyebabkan selulosa yang dihasilkan tinggi. Penelitian ini didukung oleh penelitian Jannur, (2015). Kadar air pada Nata merupakan hasil presentase pembagian antara berat air yang hilang dengan berat Nata mulamula, tinggi rendahnya kadar air pada Nata tergantung pada kemampuan Acetobacter xylinum dalam merombak gula dalam media menjadi selulosa.

Menurut penelitian Indhira (2017). lama fermentasi dapat menyebabkan selulosa hasil sekresi Acetobacter xylinum akan berikatan kuat satu dengan yang lainnya membentuk lapisan-lapisan yang terus menebal. Dan menurut penelitian Yusmarini dan Johan (2004) semakin tebalnya lapisan selulosa (polisakarida) yang terbentuk maka akan semakin rapat ikatan- ikatan selulosa, sehingga air yang terperangkap sedikit. Kandungan air yang relatif tinggi pada selulosa (Nata) disebabkan karena gugus hidroksil dari selulosa dapat berikatan dengan gugus hidrogen air (Ifadah, et al, 2016). Kadar air Nata de Milko tertinggi adalah 94,36 \% pada lama inkubasi hari ke-7 dibandingkan dengan lama inkubasi hari ke-10 (91,40 \%) dan lama inkubasi hari ke-13 $(90,16 \%)$.

\section{Kadar abu}

Tabel 4. Menunjukkan bahwa semakin lama inkubasi, kadar abu Nata de Milko yang dihasilkan nyata meningkat. Hal ini dipengaruhi oleh bahan media yang digunakan, Nata de Milko yaitu menggunakan susu substandar, menurut Winarno, (2007) susu segar mengandung bahan mineral sebesar $0,8 \%$.

Franelia (2013) menyatakan kadar abu berhubungan erat dengan kandungan mineral yang terdapat dalam suatu bahan. Kandungan mineral pada Nata de Coco berasal dari kandungan mineral yang berasal dari bahan baku Nata de Coco yaitu air kelapa. Dan penelitian ini diperkuat oleh Indhira (2017) dimana kandungan mineral ini dipengaruhi oleh besarnya kecilnya kandungan air pada masing-masing perlakuan dan karena terjadinya perubahan fisik dan kimia dari Nata tersebut. Apabila kandungan air tinggi maka kadar abu yang dihasilkan semakin kecil, begitu juga sebaliknya. bahwa kadar abu juga dipengaruhi oleh kadar air dan oleh ketebalan Nata yang dihasilkan, sehingga semakin tebal Nata yang dihasilkan maka semakin tinggi kadar abu yang diperoleh. Kadar abu Nata de Milko tertinggi adalah $0,48 \%$ pada lama inkubasi hari ke-13 dibandingkan dengan lama inkubasi hari ke-10 (0,36 \%) dan lama inkubasi hari ke-7 $(0,27 \%)$

\section{Kadar lemak}

Tabel 4. Menunjukkan bahwa semakin lama inkubasi, kadar lemak yang dihasilkan nyata meningkat. Hal ini dipengaruhi oleh terdapatnya kadar lemak pada media tumbuh Nata, dimana menggunakan susu substandar sebagai media tumbuh bakteri Nata,

Berdasarkan hasil analisis, susu substandar menggunakan Lactoscan terdeteksi lemak sebesar 3,43\%. Meningkatnya kadar lemak disebabkan oleh lama fermentasi dimana semakin lama fermentasi maka akan menghasilkan selulosa yang semakin banyak Khothibul et al (2011). Dan semakin tebalnya lapisan polisakarida yang terbentuk semakin rapat sehingga air yang terperangkap sedikit (Yusmarini et al, 2004). Sehingga lemak yang terperangkap semakin banyak. Hasil penelitian ini didukung oleh Khotibul (2011) kadar lemak yang terkandung dalam Nata merupakan lemak yang terperangkap oleh matrik Nata selama fermentasi, semakin lama fermentasi maka semakin meningkat kadar lemak . Kadar lemak Nata de Milko tertinggi adalah $0,32 \%$ pada lama inkubasi hari ke-13 dibandingkan dengan lama inkubasi hari ke-10 $(0,24 \%)$ dan lama inkubasi hari ke-7 $(0,14 \%)$

\section{Kadar protein}

Tabel 4. Menunjukkan bahwa semakin lama inkubasi, kadar protein Nata de Milko yang dihasilkan nyata meningkat. Hal ini dipengaruhi oleh lama inkubasi dimana semakin lama inkubasi protein yang dihasilkan semakin meningkat.

Terdapatnya protein pada Nata de Milko ini disebabkan karena dalam susu substandar mengandung protein sebesar protein 2,22\% berdasarkan analisis menggunakan Lactoscan MCC50. Penelitian ini didukung oleh Siti, (2006) bahwa perlakuan lama fermentasi 14 hari fermentasi menghasilkan kadar protein lebih tinggi dibandingkan dengan fermentasi 7 
hari pada pembuatan Nata de Soya. Kecilnya nilai protein Nata de Milko yang dihasilkan kemungkinan terjadi leaching pada saat pencucian dan pemanasan, pada penelitian ini semua perlakuan disamakan dengan standard Nata dalam kemasan. Kadar protein Nata de Milko tertinggi adalah 0,61 \% pada lama inkubasi hari ke-13 dibandingkan dengan lama inkubasi hari ke-10 (0,47 \%) dan lama inkubasi hari ke-7 $(0,34 \%)$.

\section{Kadar karbohidrat}

Tabel 4. Menunjukkan bahwa semakin lama inkubasi, kadar karbohidrat yang dihasilkan nyata meningkat. Analisa karbohidrat ini merupakan suatu analisis di mana kandungan karbohidrat termasuk serat kasar diketahui bukan melalui analisis tetapi melalui perhitungan dengan menggunakan persamaan: \% Kadar Karbohidrat $=100 \%$ (kadar air + kadar abu + kadar lemak + kadar protein) (Winarno 1997).

Berdasarkan lama inkubasi kadar karbohidrat Nata de Milko semakin meningkat hal ini dipengaruhi oleh besar dan komponen nutrisi yang terdapat pada masing-masing perlakuan dimana semakin besar nilai komponen nutrisi (kadar air, kadar abu, kadar lemak dan kadar protein) maka akan semakin kecil kadar karbohidrat, dan sebaliknya apabila semakin kecil nilai komponen nutrisi akan semakin besar.

Hasil penelitian ini didukung oleh Fatkurahman et al (2012) bahwa kadar karbohidrat yang dihitung secara by difference dipengaruhi oleh komponen nutrisi lain yaitu protein, lemak, air, dan abu. Semakin tinggi komponen nutrisi lain maka kadar karbohidrat semakin rendah dan sebaliknya apabila komponen nutrisi lain semakin rendah maka kadar karbohidrat semakin tinggi. Kadar karbohidrat Nata de Milko tertinggi adalah $8,43 \%$ pada lama inkubasi hari ke-13 dibandingkan dengan lama inkubasi hari ke-10 $(7,54 \%)$ dan lama inkubasi hari ke-7 (4,89\%).

\section{Kesimpulan}

Lama inkubasi berpengaruh terhadap karakteristik fisik dan kimia. Nata de Milko dari susu substandar, perlakuan yang terbaik adalah lama inkubasi 13 hari dengan nilai rendemen $43,65 \%$, ketebalan $1,74 \mathrm{~cm}$, tekstur $70,08 \mathrm{~mm} / \mathrm{g} / \mathrm{dt}$, kadar air $90,16 \%$, kadar abu $0,48 \%$, kadar lemak $0,32 \%$, kadar protein $0,61 \%$ dan karboidrat $8,43 \%$.

\section{Daftar Pustaka}

AOAC. 1990. Officials Methods of Analysis of The Association of Official Chemist. Washington. DC.

AOAC. 1995. Officials Methods of Analysis of The Association of Official Chemist. Washington. DC.

AOAC. 2007. Officials Methods of Analysis of The Association of Official Chemist 18 th edn. Gaithersburg. MD.

Alwani, H. dan Kristiono. 2013. Pengaruh Penambahan Sumber Nitrogen Terhadap Hasil Fermentasi Nata De Coco. Jurnal Momentum. 9(1):62-65.

Badan Pusat Statistik. Produksi Susu Segar menurut Provinsi 2009-2016, http://www.bps.go.id/linkTableDinami s/viewid/1083. [23 Maret 2018].

Badan Standardisasi Nasional. 2011. Syarat Mutu Susu Segar. SNI 3141.1:2011. Badan Standardisasi Nasional Indonesia. Hal:2-4.

Badan Standardisasi Nasional. Syarat Mutu Nata Dalam Kemasan. SNI 01.4317:1996. Badan Standardisasi Nasional Indonesia. Hal:1-4.

Dwi, A., Abdullah, B, Arif., Agus, B. dan Wahyu, D. 2015. Analisis Parametrik dan Non Parametrik Pengaruh Konsentrasi Sukrosa dan Amonium Sulfat Terhadap Mutu Nata De Melon. Informatika Pertanian. 24 (1):101-108.

Fatkurahman, R., W. Atmaka dan Basito. 2012. Karakteristik sensoris dan sifat fisikokimia cookies dengan substitusi bekatul beras hitam (Oryza sativa L.) dan tepung jagung (Zea mays L.). Jurnal Teknosains Pangan. 1(1):49-57.

Fifendy, M., D.H. Putri dan S.S. Maria. 2011. Pengaruh penambahan touge sebagai sumber nitrogen terhadap mutu Nata de kakao. Jurnal Sainstek. 3(2):165170.

Franelia, A, Laras., Zakiatulyaqin, dan Suko. 2013 Pengaruh Lama Penyimpanan Air Kelapa Dan Konsentrasi Gula Pasir Terhadap Karakteristik Dan Organoleptik Nata De Coco. Jurnal Sains Mahasiswa Pertanian. 2(2):1-12.

Hardi, M, R., Dewi, M, P. dan Abdullah, S. 2013. Pengaruh Penambahan Gula, Asam Asetat Dan Waktu Fermentasi Terhadap Kualitas Nata De Corn. Jurnal Teknik Kimia. 1(19):34-39. 
Hartati, Chairunnisa. 1997. Isolasi Dan Modifikasi Protein Susu Dalam Rangka Pemanfaatan Susu Sapi Substandar. Disertasi. Institut pertanian Bogor.

Hartati, C., Roostita L, B., Andry, P., Dadan, H, R. 2017. Karakteristik Kimia Set Yoghurt Dengan Bahan Baku Susu Tepung Dengan Penambahan Jus Bit (Beta Vulgaris L.). Jurnal Ilmu Ternak. 17(1):35-39.

Iguchi, M., Yamanaka, S. and A. Budhiono. 2000. Bacterial Cellulose A Masterpiece Of Nature's Arts. Journal Of Material Science. 35(2):261-270.

Indah, P., dan Siti, A. 2013. Mutu Fisik, Kadar Serat dan Sifat Organoleptik Nata de Cassava Berdasarkan Lama Fermentasi. Jurnal Pangan dan Gizi. 04(07):29-38.

Indhira, S. 2017. Peningkatan Protein dan Vitamin B melalui Pemberian Whey dan Lerry pada Produk Nata. Jurnal Info Kesehatan. 15(2): 495-506

Junaidi, H, M., Ardyati, T, dan Suharjono. 2010. Uji Potensi Microbacterium Sp. Dan Penambahan Daun Orok-Orok (Crotalaria Sp.) Dalam Dekomposisi Jerami Padi, Tesis, Fakultas Matematika dan Ilmu Pengetahuan Alam Jurusan Biologi Universitas Brawijaya, Malang.

Jannur, M., Bambang D, A., dan Wahyunanto, A, N. 2015. Pengaruh Penambahan Sukrosa dan Lama Fermentasi Terhadap Kadar Serat Nata Dari Sari Nanas (Nata de Pina). Jurnal Keteknikan Pertanian Tropis dan Biosistem. 3 (1), 80-85.

Khairul, A, Z., Khairunnisa, N., Mahfuzah M., dan Mohd N, M, Z. 2015. Effect of Incubation Temperature on Growth of Acetobacter xylinum 0416 and Bacterial Cellulose Production. Journal Applied Mechanics and Materials. 815:3-8.

Khothibul, U, A, A., Anindhita, P., dan Lilik, E, R. 2011. Pengaruh Penggunaan Persentase Starter Dan Lama Inkubasi Yang Berbeda Terhadap Tekstur, Kadar Lemak Dan Organoleptik Nata De Milko. Jurnal Ilmu dan Teknologi Hasil Ternak. 6(2):26-35.

Keshk, S.M.A.S., Razek, T.M.A., and Sameshima, K. (2006). Bacterial cellulose production from beet molasses. African Journal of Biotechnology. 5 (17): 1519-1523.

Marwati, H, S. dan Ratri H. 2013. Pengaruh Konsentrasi Gula dan Starter terhadap Mutu Teh Kombucha. Jurnal Teknologi Pertanian. 08 (02):49-53.

McDonald P, Edwards RA, Greenhalgh JFD and Morgan CA. 2002. Animal Nutrition. 6th Ed. London (GB). Pretice all.Naidu, A. S. 2000. Natural Food Antrimicrobial System. New York : CRC Press.

Nainggolan, J. 2009. Kajian pertumbuhan Bakteri Accetobacter sp. Dalam Kombucha-Rosela Merah (Hibiscus sabdariffa) pada Kadar Gula dan Lama Fermentasi yang Berbeda. (Tesis). Universitas Sumatera Utara. Medan:

Nugroho D, A., dan Pradipta A. 2015. Characterization of Nata de coco produced by fermentation of immobilized Acetobacter xylinum. Agriculture and Agricultural Science Procedia. Science Direct. 3(2015):278282.

Raida, A, I., Joni, K., dan Sudarma, D, W. 2016. Strain Improvement Acetobacter Xylinum Menggunakan Ethyl Methane Sulfonate (Ems) Sebagai Upaya Peningkatan Produksi Selulosa Bakteri. Jurnal Pangan dan Agroindustri. 4(1):273-282.

Raghunathan, D. 2013. Production of microbial celullose from the new bacterial strain isolated from temple wash waters. International Journal Current Microbiology Application Science. 2(12):275-290.

Roostita L, B., Hartati C., Obin, R., Eka, W. 2011. Derajat Keasaman Dan Karakteristik Organoleptik Produk Fermentasi Susu Kambing Dengan Penambahan Sari Kurma yang Diinokulasikan Berbagai Kombinasi Starter Bakteri Asam Laktat. Junal Ilmu Ternak. 11(1):49-52.

Shihata A and Shah NP 2000. Proteolytic Profiles of Yogurt and probiotic bacteria. International Dairy Journal.10(5):401-408.

Siregar SB. 2001. Peningkatan kemampuan berproduksi susu sapi perah laktasi melalui perbaikan pakan dan frekuensi pemberiannya. JITV. 6(2):76-82. 
Sukarni. 2006. Produksi dan kualitas air susu kambing Peranakan Ettawa yang diberi tambahan urea molases blok dan atau dedak padi pada awal laktasi. J Animal Production. 1:427-441.

Susilorini, T. E. dan M. E. Sawitri, 2007. Produk Olahan Susu. Penebar Swadaya. Depok. Jawa Barat.

Suwito, W. 2010. Bakteri yang Sering Mencemari Susu: Deteksi, Patogenesis, Epidemiologi, dan Cara Pengendaliannya. Jurnal Litbang Pertanian. 29(3): 96-100.

Siti, N. 2006. Kajian Pengaruh Kadar Gula Dan Lama Fermentasi Terhadap Kualitas Nata De Soya. Jurnal
Matematika, Sains dan Teknologi. $7(1): 40-47$.

Winarno F.G. 1997. Kimia Pangan dan Gizi. PT Gramedia Pustaka Utama. Jakarta.

Winarno, F.G. 2007. Pangan Gizi, Teknologi dan Konsumen. PT. Gramedia Pustaka Utama. Jakarta

Yusmarini, U, Pato. dan V,S, Johan. 2004. Pengaruh Pemberian Beberapa Jenis Gula dan Sumber Nitrogen terhadap Produksi Nata de Pina. Jurnal SAGU. 3(1):20-27.

Zakaria, Y., Helmy, MY., dan Safara, Y. 2011. Analisis Kualitas Susu Kambing Peranakan Etawah yang Disterilkan pada Suhu dan Waktu yang Berbeda. Jurnal Agripet. 11(1):29-31. 